\title{
21 世紀の社会経済環境の構造変化に対応したトリップ発生モデル* \\ Trip Generation Model Considering Structural Changes in \\ Socioeconomic Environment in the 21st Century *
}

土井利明** 柴田洋三***

by Toshiaki DOI ** and Yozo SHIBATA ***

1.はじめに

国土軸に該当し得る新幹線の計画（例えば、中央新 幹線）の特徴として、東海道以降の例を見ても、その 地域、ひいては国土全体に与える影響は極めて大き く、しかも計画、建設期間、さらには開業から真に国 土に根付くための期間が非常に長期にわたるため、 計画の段階においては長期的展望のもと、国土全体 の長期計画との整合性を踏まえ進めていくことが必 要となる。

その一方、需要予測のベースとなる社会経済環境は といえば、21世紀を目前にして、国内外ではバブル の崩壊や冷戦構造の終結、さらには地球環境保全な どを機にした様々な変革が生じ、社会システムが大 きく変わろうとしている。

このような条件下のもと、今後の新たな新幹線計画 においては、上記のような新幹線計画の特徵を考虑 し、長期的な展望の中で、今後の社会経済環境の構造 変化を考虑して進めていく必要があるというのが筆 者らの問題意識である。

さらには、国鉄改革により新幹線の建設にあっては 国、地元、鉄道事業者などがその受益に応じた負担を 求められている。したがって、地元住民、ひいては国 民全体の便益の最大化、鉄道事業者の健全経営など、 今後の新幹線計画には国民全体の論議の中での合意 が必要となってくる。そのためには、より定量的な検 討を行う中で、さまざまなケースを想定した十分な 論議を踏まえて進めていくことが重要といえる。 上記のような問題意識のもと、筆者らは、今後の社 会経済環境の構造変化に対応した需要予測手法とし て意思決定手法であるAHP（A口alytic Hierarchy

*キーワード：計画手法論、発生交通、鉄道計画

**正員、工修、東海旅客鉄道（侏）新幹線鉄道事業本部 施設部長

（東京都千代田区丸の内 1-6-5、TEL03-3240-5532、 FAX03-3213-2357)

***正員、工修、東海旅客鉄道（株）総合企画本部 中央新 幹線計画部

(東京都中央区八重洲 1-6-6、TEL03-3274-9757、 FAX03-5255-6774)
Process）手法を用いたモデルの提案 1)2)を行ってい る。

本研究では、上記の新たな需要予測手法の考え方、 及びその中での発生モデルを紹介し、本モデルを使 い、いくつかの社会経済環境の構造変化のシナリオ のもとでの将来の発生交通量の試算を行い、その変 動について評価を行う。

\section{2. 既往の研究経緯}

発生交通量想定モデルは、従来より様々な研究が行 なわれてきている。これらの中で、主に利用されるモ デルとしては原単位法、回㷌モデル法であり、今回の モデルも、基本的には前者の原単位法を利用したモ デル化となっている。また、構造変化の対応について は、今後予想される情報化の影響による交通需要へ の影響を考慮した研究 ${ }^{3)}$ があるが、余暇活動の志向 性にまで着目してモデル化を行なった例は見あたら ない。一方、A H P 適用といった観点から見ると、 機関選択モデル4)や地域の魅力5)の想定に用いられ た事例があるが、発生交通量に適用した事例は見あ たらない。

\section{3.提案する輀要予測手法の考え方と概要}

\section{(1) 需要予測の考え方}

1.で述べた新幹線計画の位置づけ、及び特徴か ら、次の 3 つの事柄が新幹線計画における需要予测 として重要と考える。

1）社会経済環境の変化に対応していること。

2）価值観の変化に対応していること。

3）関係者の合意の得られる算定手法であること。 そのために、様々なシナリオのもとに需要を予测 し、かつその過程において需要構造を明らかにしよ うと試みるわけで、それは「そもそも、今後の社会経 済環境の構造変化自体は、言うまでもなく予測が困 難である。需要予測にあたり特定化することは、たと えその結果としての予測精度が高かったとしても、 予測時点での客観性を欠くとのそしりは免れること ができない。したがって、需要予测に対する各階各層 
の支持を得るためには、個々の社会・経済情勢の予測 にそれぞれ対応した計算を行うことが必要であり、 これらの主観的計算秸果の集合が客観的な予測とな り得るとの考えが最も合理的である」と考えるから である。

\section{4. 発生モデルの概要}

(1) モデル化の考え方

トリップ発生量に今後の社会経済環境の構造変化が 与える影響を想定し、そのキーワードをまとめたも のが表1である。

表 1 発生量を左右する構造変化

\begin{tabular}{|c|c|}
\hline \multicolumn{2}{|r|}{ キーワート } \\
\hline $\begin{array}{r}\text { 人口構造の } \\
\text { 変化 }\end{array}$ & $\begin{array}{l}\text { 高龄化 } \\
\text { 少子化 }\end{array}$ \\
\hline 情報化 & \begin{tabular}{|l} 
通信㙨器への代替 \\
情報增大による誘登
\end{tabular} \\
\hline $\begin{array}{r}匕^{\prime}: \dot{i}^{2} \times x y 1 k \\
\text { の変化 } \\
\end{array}$ & $\begin{array}{l}\text { 労的時間短縮 } \\
\text { 就業形瞋の多様化 }\end{array}$ \\
\hline $\begin{array}{r}\text { 余眼活動の } \\
\text { 变化 }\end{array}$ & \begin{tabular}{|l} 
余喓時間の增大 \\
余喓の多様 \\
価値観の変化
\end{tabular} \\
\hline 国際化 & 海外旅行の增大 \\
\hline
\end{tabular}

ビジネストリッブでは、今後の労働時間短縮（以後 「時短」)の動向、及び情報化の進路にあわせてビジネ スのあり方がいかに変わるかというところが、発生 量の変動要素といえる。

また、ブライベートトリッブでは、いわゆる高齢 化、少子化の影響で人口構造が大きく変わること、及 び時短により余暇時間が増大し、併せて価値観の多 様化などにより、余暇活動がどう変わるかというと ころが発生量の変動要素といえる。

こういった事柄を表現する手法として、既に述べた A H P 手法を利用している。A H P 手法は、ビッッ バーグ大学Thomas L.Sa aty 教授が提唱した手法で、 複雑な状況下において、その判断要素を階層構造に 整理し、各要素の重要性を一対比較によって評価す ることにより、代替案の選択を決定する、意思決定手 法である。6)

この手法を適用したのは、判断要素を階層構造に分 解することで、問題を構造的に整理することができ、 各判断要素の重み付けは、梯々な構造変化に対応し て行え、様々なシナリオ（各階各層の主観的予測）を 反映できる。さらに上記重み付けを変化させること で、各要素の感度分析が行えるという理由からであ る。

一方、A H P 手法の課題として、設定する階層構造 の同定及び検定、さらにはその構造のもとでの計量
化（要因の重み付け）の妥当性を評価する客観的指標 が得られないことが挙げられる。

これらの課題に対してまず、階層構造については実 際に行動するときの判断の志向バターンを再現する ことで、同意の得られやすい、しかもシナリオとリン クした形での重み付けがやりやすい構造とし、また 重み付けについては 2010 年委員会報告（経済審 議会、平成 3 年) など、公的な予测デー夕をできる限 り使うことでシナリオライティングを極力減らし、 データのないものについては、筆者らを含め 5 名の ワーキンクの合意のもとで行うこととした。

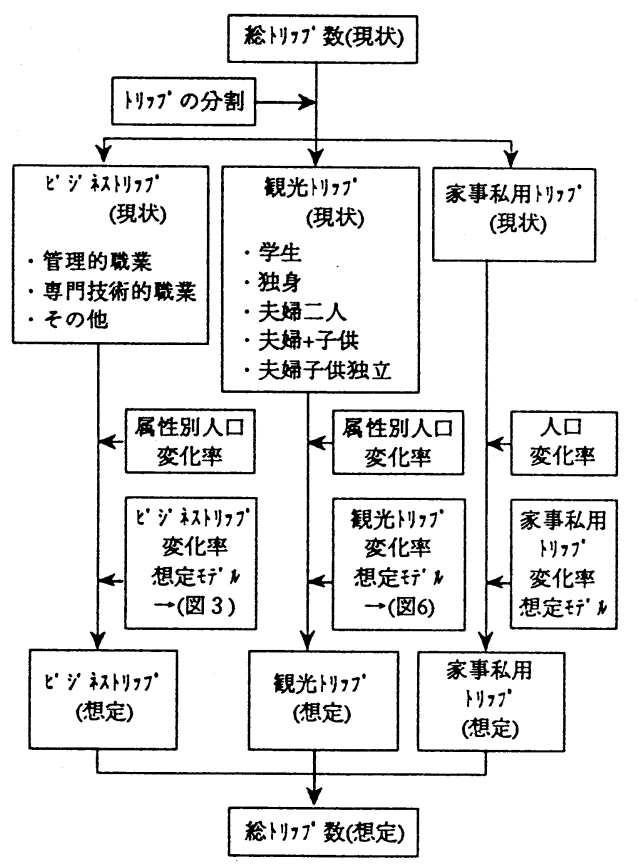

図 1 トリップ発生量の想定フロー

（2）トリップ発生量の想定フロー

図1にトリップ発生量の想定フローを示す。まず、 現状のトリッブ量をビジネ、、観光、家事私用と目的 別に分類し、さらに個々について、トリップの性質を 考慮し属性別に分割している。

この分割した個々のトリッブ数に対し、後述するA $\mathrm{H} \mathrm{P}$ 手法等を用いた目的別トリッブの変化率と、各 属性別の人口変化率をかけることによって、将来の 属性別交通量を求めることとしている。

また本モデルでは、トリッブの目的別にその属性を 表 2 のように分割し、構成の変化、価值観の多用化な どに対応できるようにしている。 
表 2 本モデルのトリップのセグメント

\begin{tabular}{|c|c|}
\hline トリップ目的 & けリフプ主体 \\
\hline ピジ 祙リリフプ & $\begin{array}{l}\text { 管理的職業従事者 } \\
\text { 専門·技術的職業従事者 } \\
\text { その他の職業従事者 }\end{array}$ \\
\hline 観光けリフプ & $\begin{array}{l}\text { 学生 } \\
\text { 独身 } \\
\text { 夫婦二人 } \\
\text { 夫婦+子供 } \\
\text { 夫婦子供独立 }\end{array}$ \\
\hline 家事·私用トリ97 & セグメント分割せず \\
\hline
\end{tabular}

(3) ビジネストリップ発生モデル

図 2 に、ビジネストリップの一人当たりのトリップ 発生量変化率の想定手順を示す。

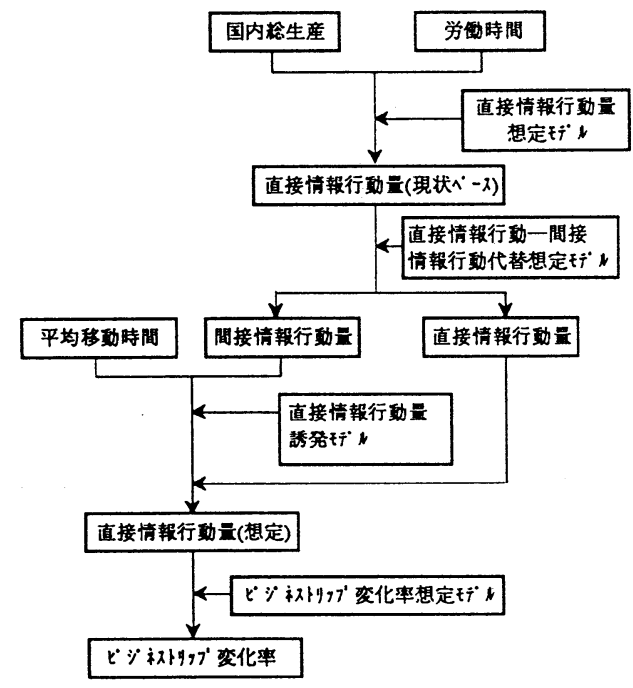

図2ヒジストリップ発生量想定フロー

本モデルでは、トリップ量そのものに着目するので はなく、直接情報行動量（定義：Face to F a c e で顧 客や訪問者と面談、会議・打ち合わせ、決済に費やす 時間。単位は分/日）の変化に着目してモデル化を 行っている。

直接情報行動量については参考文献7)に実測及び 予測値のデータがあり、この值を就業者 1 人当たり の G D P と労働時間変化を考虑して線形回帰モデル を作成すると、相関係数0.91が得られる。このモデ ル（直接情報行動量想定モデル）によって将来の直接 情報行動量を求めることとした。

このモデルに予測年の G D P、就業者数や労働時間 を入力データとして算出した值は、現状をべースと した将来の直接情報行動量と考えられるため、構造 変化に十分対応しているとはいえない。一方、将来動 向を鑑みると、情報化の進展は必至であり、情報通信
を利用した直接情報行動の間接情報行動（定義：電 話、手紙等メディアに接触する時間)への転換が予想 される。本モデルでは A H P を利用し、困 3 のような 階層図のもとで一対比較を行い代替率を想定した （直接情報行動量 - 間接情報行動量代替想定モデル）。

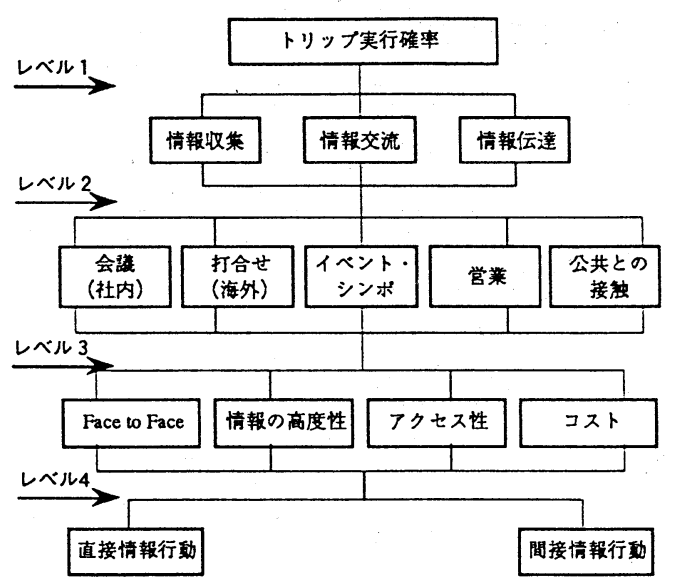

図 3 間接情報行動への代替比率想定階層困

このようなトリップの情報機器への代替が生じる と、従来ならば移動に費やすと考えられる時間が、別 の業務に向けられ、新たな情報行動が生じることが 考えられる。そこで新たに誘発される直接情報行動 量を想定するモデル（直接情報行動量誘発モデル）を 作成した。具体的には、直接情報行動量と移動時間、 先に想定した直接情報行動から間接情報行動への代 替率を行動量の分担率と読み換え、これらを利用し て無限等比級数の和として㷌着した。

一方、マストラ交通量を目的変数とし、直接情報行 動量を説明変数として線形回帰モデルを作成すると、 相関係数が0.93 程度のモデルが作成される（ビジネ ストリップ量変化率想定モデル)。このモデルを利用 して、図 4 に示したように直接情報行動量の変化か らビジネストリップの変化率を想定した。

\section{(4) 観光トリップ発生モデル}

8）国内観光トリップ発生モデルの全体像

モデルのフローは図 5 に示す通りである。余暇活動 の志向性及び具体的活動を選択し、制約条件によっ て実行可能かどうかが選別され、可能であれば決定、 不可能な場合は再度余暇活動を選択するという流れ を持たせ、実際の余睱活動を決定する思考パターン をてデル化したものである。

実行可能な余暇活動の割合が決定すると、それぞれ の活動におけるマストラ利用率と、そもそもの余暇 活動時間を考慮し、余暇活動におけろトリップ発生 
量を求める。

なお、マストラ利用率は文献8) の利用交通機関の アンケート結果、余暇活動は労働時間の短縮分が余 暇時間の増大であるとした。

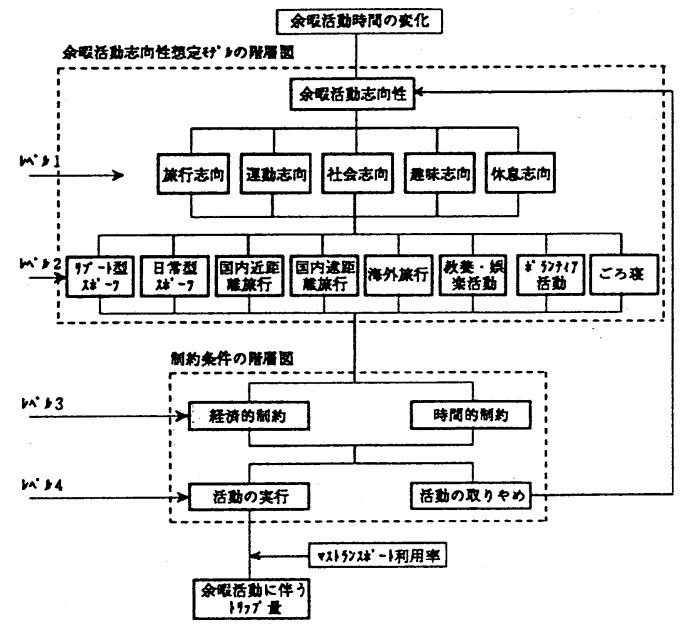

図 5 観光トリッブ発生モデルのフロー

\section{b) 余睱活動志向性想定モデル}

余嘏活動志向性想定モデルとして、困 5 の点線で囲 まれた階層構造を持つ A H P 手法を用いた。例えば、 長期休层の導入が進み、長期の旅行が増加すると いった構造変化に対しては、階層図で示された旅行 志向や国内遠距噰旅行、海外旅行の重み付けを增す ことによって対応ができる。

c) 制䄪条件の考え方
上記モデルで選択された余层活動はあくまでも潜在 的な希望である。実際には様々な制約を受ける中で、 志向性が高くかつ制約条件をクリアする余暇活動が 決定される。本モデルでは、制䄪条件として時間的制 䄪と経済的制約を取り上げた。また、手法としては、 ここでも A H P 手法を適用している。

（5）家事私用トリップ発生モデル

家事私用トリップについては、冠婚葬祭や帰省と いったトリッブであり、その発生のメカニズムは現 状も将来も変化がないことが予想される。よって本 研究では、家事私用トリッブについては、発生量変化 率は 1 と仮定してモデル化を行なった。

\section{5.トリップ発生量の想定}

\section{（1）評価すべき課題の設定}

今後予想される社会経済環境の構造変化に対応し て、次の課題について検討する。

1）今後の社会経済環境の構造変化の影響を、想定 される標準的なシナリオのもとで評価する。

2）上記シナリオに含めた構造変化のうち、変動要 素の大きいと考えられる要因の中から、次の点 をビックアップし、その変動による影響を評価 する。

ア、時短の進渉による影響

1、情報化の進渉による影響

ウ，余睱活動志向性の変化による影響

エ、余暇活動の制約要因のうち経済的制約による 影響

\begin{tabular}{|c|c|c|c|c|c|}
\hline & \multicolumn{2}{|c|}{$\begin{array}{c}\text { 直接情報行動量 } \\
\text { 想定㹸 }\end{array}$} & 直接情報行動量誘発无デル & \multicolumn{2}{|c|}{$\begin{array}{c}\text { ピジ祏リップ量変化率 } \\
\text { 想定㳯 }\end{array}$} \\
\hline $\mathrm{\epsilon} \overline{\mathrm{j}}$ ルの形 & 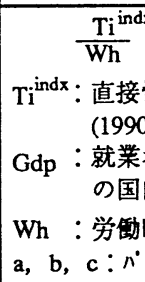 & $\begin{array}{l}a G d p+b \\
\text { 報行動量 } \\
\text { =1) } \\
\text { 数 } 1 \text { 人あたり } \\
\text { 総生産 }(1990=1) \\
\text { 間 }(1990=1) \\
x-4\end{array}$ & $\begin{array}{l}\text { 初項 } \quad \frac{\alpha \beta \mathrm{TtTi}}{\mathrm{Ti}+\mathrm{Tt}} \\
\text { 項比 } \quad \frac{\beta \mathrm{Tt}}{\mathrm{Ti}+\mathrm{Tt}} \\
\text { の等比級数の和として㷌着 } \\
\end{array}$ & $\begin{array}{l}\text { Trip= } \mathrm{cTi}^{\text {in }} \\
\text { Trip }: \text { ? } \\
\mathrm{Ti}^{\text {ind }}: \frac{1}{1} \\
\mathrm{c}, \mathrm{d}: \text { n }\end{array}$ & $\begin{array}{l}+\mathrm{d} \\
\text { 交通量 } \\
0=1) \\
\text { 情報行動量 } \\
0=1) \\
-9\end{array}$ \\
\hline $\begin{array}{r}ハ^{\prime} ラ x-タ \text { 值 } \\
\text { （）内は } \\
\mathrm{t} \text { 値 }\end{array}$ & $\begin{array}{c}b \\
\text { 相関係数 }\end{array}$ & $\begin{array}{l}0.2725(2284) \\
0.907\end{array}$ & $\begin{array}{c}\mathrm{Ti}: \text { 新たに誘発される } \\
\text { 直接情報行動量 (分) } \\
\mathrm{Ti}: \text { 直接情報行動量 (分) } \\
\mathrm{Tt}: \text { 移動に要する時間 (分) } \\
\alpha: \text { 直接情報行動分担率 } \\
\beta \text { : 間接情報行動分担率 }\end{array}$ & 相関係数 & $0.320(2.300)$ \\
\hline
\end{tabular}

図 4 ヒジネストリップの発生交通量变化率想定に利用したモデルの概要 


\section{(2) シナリオの設定}

上記の評価に対し、表 3 のとおり標準的なシナリオ 1 と、個々の構造変化がより加速度的に進んだシナ リオ 2 のつのシナリオを設定した。

なお本論文においては、ビジネストリップ等を追加 したことから講演論文 ${ }^{2)}$ とは、シナリオ1が変更と なっている。

\section{(3) ビジネストリップ発生量の想定}

a）直接情報行動量（現状ベース）の想定

G D P の推移を表 3 のシナリオのように仮定し、各 シナリオの労働時間を仮定した結果として、表 4 に 示す情報行動量（現状ベース）が推計される。

なお、ここでは属性毎の違いは考虑していない。

表 3 設定シナリオ

\begin{tabular}{|c|c|c|}
\hline & シナリオ 1 & シナリオ 2 \\
\hline 時 & $\begin{array}{l}\text { 労微時間が短縮され，年 } \\
\text { 間労鱽時間か5180時間程 } \\
\text { 度となる }\end{array}$ & 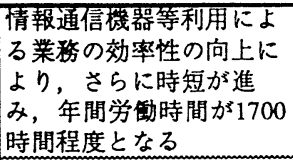 \\
\hline $\begin{array}{l}\text { 情 } \\
\text { 報 } \\
\text { 化 }\end{array}$ & 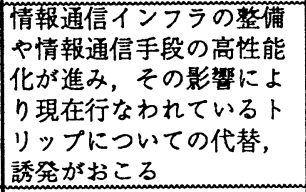 & 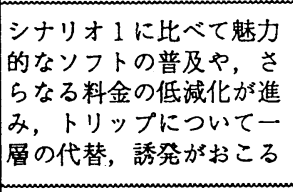 \\
\hline $\begin{array}{l}\text { 刹 } \\
\text { 溊 } \\
\text { 活 } \\
\text { 志 } \\
\text { 向 } \\
\text { 性 }\end{array}$ & $\begin{array}{l}\text { 余㗇をゅっくりと楽しむ } \\
\text { という志向が強まり, } \\
\text { 行志向, 休息志向が高く } \\
\text { なる }\end{array}$ & $\begin{array}{l}\text { 余昵を活発に楽しむよう } \\
\text { になり，旅行志向が大き } \\
\text { く拡大する }\end{array}$ \\
\hline 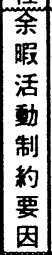 & $\begin{array}{l}\text { 労锥時間短縮を受けて, } \\
\text { 可処分時間が增加, また } \\
\text { 経济成長をを背とした可 } \\
\text { 処分所得も增加する }\end{array}$ & $\begin{array}{l}\text { シナリオ1 } 1 \text { と比べて一層 } \\
\text { 労㑬時間が短樎するこ } \\
\text { から, 可処分時間がさら } \\
\text { に増加する }\end{array}$ \\
\hline $\begin{array}{l}G \\
D \\
P\end{array}$ & $\begin{array}{l}\text { 1990年代2 3\%，2000年1 } \\
\text { 成長が推移し，2010年で6 }\end{array}$ & $\begin{array}{l}\text { たk1〜2\%程度で経済 } \\
\text { 20兆円程度となる }\end{array}$ \\
\hline
\end{tabular}

表 4 シナリオ別の直接情報行動量（現状ベース） （分/日）

\begin{tabular}{|c|c|}
\hline & 情報行動量（現状ペース） \\
\hline 現状 & 46.3 \\
\hline シナリオ1 & 55.6 \\
\hline シナリオ 2 & 51.1 \\
\hline
\end{tabular}

\section{b）直接情報行動量（想定值）の想定}

図 3 に示した階層図の重み付けを表 5 の方針のもと に求めた結果を表 6 、表 7 に示す。

この結果より、図 4 に示した式を用い、代替及び誘 発を考虑した属性別の直接情報行動量 (想定值)とし て、表 8 のように求められる。なお想定に際して、

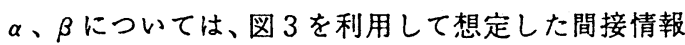
行動量代替比率を直接情報行動量、間接情報行動量 分担比率と読み变えて利用し、 $\mathrm{T} t$ は、平成元年度東 京都市圈のバーソントリッブ調査による1日のト リッブ時間データを利用した。

表 5 重み付けの方針

\begin{tabular}{|c|c|c|c|c|c|c|c|c|}
\hline \multirow{2}{*}{\multicolumn{3}{|c|}{$\begin{array}{c}\text { 图 } 4 \text { における } \\
\text { 各項目 }\end{array}$}} & \multicolumn{3}{|c|}{ シナリオ 1} & \multicolumn{3}{|c|}{ シナリオ 2} \\
\hline & & & \multirow{2}{*}{\begin{tabular}{|c} 
管理的 \\
联羓 \\
$-\triangle$ \\
\end{tabular}} & \multirow{2}{*}{ 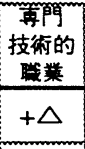 } & \multirow{2}{*}{$\begin{array}{c}\text { その他 } \\
\text { の㵵業 } \\
-\triangle\end{array}$} & \multirow{2}{*}{$\begin{array}{c}\begin{array}{c}\text { 管理的 } \\
\text { 職羓 }\end{array} \\
-\bigcirc\end{array}$} & \multirow{2}{*}{ 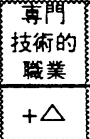 } & \multirow{2}{*}{ 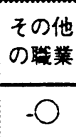 } \\
\hline 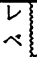 & & $\begin{array}{l}\text { 情冁 } \\
\text { 交流 }\end{array}$ & & & & & & \\
\hline $\begin{array}{l}U \\
1 \\
\end{array}$ & & $\begin{array}{l}\text { 倩溒 } \\
\text { 伝達 } \\
\end{array}$ & $-\Delta$ & & $-\Delta$ & $-\Delta$ & & $-O$ \\
\hline \multirow{6}{*}{ 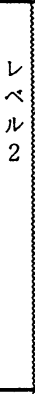 } & 情 & 会議 & $-\Delta$ & $-\Delta$ & $-\Delta$ & -0 & -0 & -0 \\
\hline & & $\begin{array}{l}\text { 公簧と } \\
\text { の接触 }\end{array}$ & $-\triangle$ & $-\Delta$ & $-\Delta$ & $-\Delta$ & $-\Delta$ & $-\Delta$ \\
\hline & 情 & 会䛾 & $-\Delta$ & $-\Delta$ & $-\Delta$ & -0 & -0 & -0 \\
\hline & 却 & $\begin{array}{c}\text { 打ち } \\
\text { 合わせ }\end{array}$ & & $+\triangle$ & & & $+\Delta$ & \\
\hline & 流 & $\begin{array}{l}\text { 公共と } \\
\text { の接触 }\end{array}$ & & & -0 & & & -0 \\
\hline & $\begin{array}{l}\text { 埥 } \\
\text { 伝 } \\
\text { 達 } \\
\end{array}$ & $\begin{array}{l}\text { 公共と } \\
\text { の接触 } \\
\end{array}$ & $-\Delta$ & & & $-\Delta$ & & \\
\hline \multirow{12}{*}{$\begin{array}{c}\sim \\
\sim \\
\sim \\
3\end{array}$} & \multirow{3}{*}{ 会 } & \multirow{3}{*}{$\begin{array}{c}\text { Face } \\
\text { to Face } \\
\text { W箐報 } \\
\text { 高度化 } \\
\text { בスト }\end{array}$} & -0 & -0 & -0 & -(9) & -(O) & -(0) \\
\hline & & & $+\Delta$ & $+\Delta$ & $+\Delta$ & +0 & +0 & +0 \\
\hline & & & $+\Delta$ & $+\triangle$ & $+\triangle$ & +0 & +0 & +0 \\
\hline & \multirow{4}{*}{$\begin{array}{l}\text { fo } \\
\text { 合 } \\
\text { † } \\
\text { せ }\end{array}$} & $\begin{array}{c}\text { Face } \\
\text { to Face }\end{array}$ & & $-\triangle$ & & & -0 & \\
\hline & & $\begin{array}{l}\text { 稫霞の } \\
\text { 高度化 }\end{array}$ & & $+\Delta$ & & & $+\triangle$ & \\
\hline & & $\begin{array}{l}\text { アク } \\
\text { ス性 }\end{array}$ & & $+\triangle$ & & & $+\triangle$ & \\
\hline & & コスト & $+\Delta$ & $+\Delta$ & $+\triangle$ & +0 & +0 & $+O$ \\
\hline & \multirow{2}{*}{ 営 } & $\begin{array}{l}\text { Face } \\
\text { to Face }\end{array}$ & & & $-\Delta$ & & & -0 \\
\hline & & コスト & & & $+\triangle$ & & & +0 \\
\hline & 共 & $\begin{array}{c}\text { Face } \\
\text { to Face }\end{array}$ & & -0 & $-O$ & & -0 & -0 \\
\hline & と & $\begin{array}{c}\text { アクセ } \\
\text { ス性 }\end{array}$ & & $+O$ & +0 & & +0 & +0 \\
\hline & 接 & בスト & & +0 & +0 & & $\xi+0$ & +0 \\
\hline \multicolumn{9}{|c|}{ 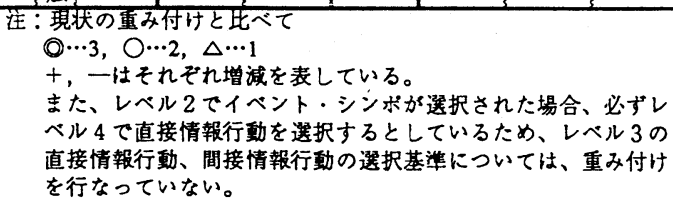 } \\
\hline
\end{tabular}


表 6 重み付け結果（シナリオ1）

\begin{tabular}{|c|c|c|c|}
\hline & 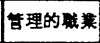 & 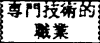 & 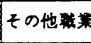 \\
\hline \multicolumn{4}{|l|}{ レヘル1，2 } \\
\hline \multirow{5}{*}{ 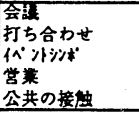 } & $20.5 \%$ & $13.7 \%$ & $25.5 \%$ \\
\hline & $36.4 \%$ & 44.3\% & 1629 \\
\hline & $11.3 \%$ & $25.6 \%$ & $7.7 \%$ \\
\hline & $25.7 \%$ & $11.5 \%$ & 4529 \\
\hline & $6.1 \%$ & $4.9 \%$ & $5.5 \%$ \\
\hline \multicolumn{4}{|l|}{ レベル 3} \\
\hline \multirow{6}{*}{ 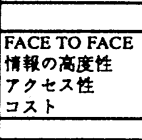 } & \multicolumn{3}{|c|}{ 会譩 } \\
\hline & $52.5 \%$ & $52.5 \%$ & $52.5 \%$ \\
\hline & $21.2 \%$ & $21.2 \%$ & $212 \%$ \\
\hline & $5.1 \%$ & $5.1 \%$ & $5.1 \%$ \\
\hline & 21.20 & $21.2 \%$ & $21.2 \%$ \\
\hline & \multicolumn{3}{|c|}{ 打ち合わ世 } \\
\hline \multirow{5}{*}{$\begin{array}{l}\text { FACE TO FACE } \\
\text { 榑の高度性 } \\
\text { フクセス性 } \\
\text { コスト } \\
\end{array}$} & $42.4 \%$ & $15.3 \%$ & $42.4 \%$ \\
\hline & $42.4 \%$ & $63.2 \%$ & $42.4 \%$ \\
\hline & $5.0 \%$ & $15.3 \%$ & $5.0 \%$ \\
\hline & $10.3 \%$ & $6.2 \%$ & $10.3 \%$ \\
\hline & \multicolumn{3}{|c|}{ 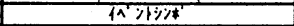 } \\
\hline \multirow{5}{*}{$\begin{array}{l}\text { FACE TO FACE } \\
\text { 赫の高度性 } \\
\text { フクセス } \\
\text { コスト } \\
\end{array}$} & $56.4 \%$ & $56.4 \%$ & $56.4 \%$ \\
\hline & $11.8 \%$ & $11.8 \%$ & $11.8 \%$ \\
\hline & $26.3 \%$ & $26.3 \%$ & $26.3 \%$ \\
\hline & $5.5 \%$ & $5.5 \%$ & $5.5 \%$ \\
\hline & \multicolumn{3}{|c|}{ 営莱 } \\
\hline \multirow{5}{*}{$\begin{array}{l}\text { FACE TO FACE } \\
\text { 情邦の高度性 } \\
\text { フクセス性 } \\
\text { コスト } \\
\end{array}$} & $59.2 \%$ & $59.2 \%$ & $31.8 \%$ \\
\hline & $30.1 \%$ & $30.1 \%$ & $31.8 \%$ \\
\hline & $5.3 \%$ & $5.3 \%$ & $31.8 \%$ \\
\hline & $5.3 \%$ & $5.3 \%$ & $4.5 \%$ \\
\hline & \multicolumn{3}{|c|}{ 公共との接貫 } \\
\hline \multirow{4}{*}{$\begin{array}{l}\text { FACE TOFACE } \\
\text { 情鉆の高度性 } \\
\text { アクセス性 } \\
\text { コスト }\end{array}$} & $43.8 \%$ & $20.0 \%$ & $20.0 \%$ \\
\hline & $43.8 \%$ & $40.0 \%$ & $40.0 \%$ \\
\hline & $6.3 \%$ & $20.0 \%$ & $20.0 \%$ \\
\hline \multirow{2}{*}{\multicolumn{4}{|c|}{ レペル4（全而倩 }} \\
\hline & & & \\
\hline & \multicolumn{2}{|c|}{ 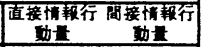 } & \\
\hline \multirow{4}{*}{$\begin{array}{l}\text { FACE TO FACE } \\
\text { 情轧の离度性 } \\
\text { フクセス姓 } \\
\text { コスト } \\
\end{array}$} & $90.0 \%$ & $10.0 \%$ & \\
\hline & $87.5 \%$ & $12.5 \%$ & \\
\hline & $\begin{array}{l}10.0 \% \\
12.5 \%\end{array}$ & $\begin{array}{l}90.0 \% \\
87.5 \%\end{array}$ & \\
\hline & $12.5 \%$ & $87.5 \%$ & \\
\hline
\end{tabular}

表 7 重み付け結果（シナリオ 2)

\begin{tabular}{|c|c|c|c|}
\hline & 管理的琙童 & 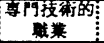 & その他職莱 \\
\hline \multicolumn{4}{|l|}{ レベル 1，2 } \\
\hline & $12.6 \%$ & $10.8 \%$ & $15.9 \%$ \\
\hline 打ち合わせ & $40.8 \%$ & 49.7\% & $16.9 \%$ \\
\hline イベットッ゙ & $12.6 \%$ & $23.8 \%$ & $8.1 \%$ \\
\hline & $27.7 \%$ & $11.1 \%$ & $53.0 \%$ \\
\hline 公共の接能 & $6.2 \%$ & 4.8\% & $6.2 \%$ \\
\hline \multicolumn{4}{|l|}{ レベル 3} \\
\hline & \multicolumn{3}{|c|}{ 会旺 } \\
\hline \multirow{5}{*}{$\begin{array}{l}\text { FACE TO FACE } \\
\text { 情轰の高度性 } \\
\text { フクセス性 } \\
\text { コスト } \\
\end{array}$} & $31.8 \%$ & $31.8 \%$ & $31.8 \%$ \\
\hline & $31.8 \%$ & $31.8 \%$ & $31.8 \%$ \\
\hline & $4.5 \%$ & $4.5 \%$ & $4.5 \%$ \\
\hline & $31.8 \%$ & $31.8 \%$ & $31.8 \%$ \\
\hline & \multicolumn{3}{|c|}{ 打ち合わせ } \\
\hline \multirow{5}{*}{$\begin{array}{l}\text { FACE TO FACE } \\
\text { 情软の高度性 } \\
\text { フクセス性 } \\
\text { コスト } \\
\end{array}$} & $39.7 \%$ & $12.5 \%$ & $39.7 \%$ \\
\hline & 39.7\% & $62.5 \%$ & $39.7 \%$ \\
\hline & $4.7 \%$ & $12.5 \%$ & $4.7 \%$ \\
\hline & $16.0 \%$ & $12.5 \%$ & $16.0 \%$ \\
\hline & \multicolumn{3}{|c|}{ 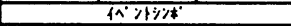 } \\
\hline \multirow{5}{*}{$\begin{array}{l}\text { FACE TO FACE } \\
\text { 情报の高度性 } \\
\text { フクセス性 } \\
\text { コスト } \\
\end{array}$} & $56.4 \%$ & $56.4 \%:$ & $56.4 \%$ \\
\hline & $11.8 \%$ & $11.8 \%$ & $11.8 \%$ \\
\hline & $26.3 \%$ & $26.3 \%$ & $26.3 \%$ \\
\hline & $5.5 \%$ & $5.5 \% !$ & $5.5 \%$ \\
\hline & \multicolumn{3}{|c|}{ 営萧 } \\
\hline \multirow{5}{*}{$\begin{array}{l}\text { FACE TO FACE } \\
\text { 情轰の高度性 } \\
\text { フクセス性 } \\
\text { コスト } \\
\end{array}$} & $592 \%$ & $59.2 \%$ & $31.3 \%$ \\
\hline & $30.1 \%$ & $30.1 \%$ & $31.3 \%$ \\
\hline & $5.3 \%$ & $5.3 \%$ & $31.3 \%$ \\
\hline & $5.3 \%$ & $5.3 \%$ & $6.3 \%$ \\
\hline & \multicolumn{3}{|c|}{ 公共との婹血 } \\
\hline FACE TOFACE & $43.8 \%$ & $8.8 \% !$ & $8.8 \%$ \\
\hline 情䎦の高度性 & $43.8 \%$ & 43.3\% & $43.3 \%$ \\
\hline フクセス陌 & $6.3 \%$ & $23.9 \%$ & $23.9 \%$ \\
\hline コスト & $6.3 \%$ & $23.9 \%:$ & $23.9 \%$ \\
\hline \multicolumn{4}{|c|}{ レベル4（全后陮て同－） } \\
\hline & \multirow{2}{*}{\multicolumn{2}{|c|}{ 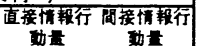 }} & \\
\hline . & & & \\
\hline \multirow{4}{*}{$\begin{array}{l}\text { FACE TO FACE } \\
\text { 情软の高度性 } \\
\text { アクセス } \\
\text { コスト } \\
\end{array}$} & $90.0 \%$ & $10.0 \%$ & \\
\hline & $87.5 \%$ & $12.5 \%$ & \\
\hline & $10.0 \%$ & $90.0 \%$ & \\
\hline & $12.5 \%$ & $87.5 \%$ & \\
\hline
\end{tabular}

表 8 直接情報行動量（想定値）（分/日）

\begin{tabular}{|l|r|r|r|}
\hline & 管理的職業 & $\begin{array}{c}\text { 専門技術的 } \\
\text { 職業 }\end{array}$ & $\begin{array}{c}\text { その他の } \\
\text { 職業 }\end{array}$ \\
\hline シナリオ 1 & 48.84 & 48.74 & 44.62 \\
\hline シナリオ 2 & 44.31 & 43.79 & 39.71 \\
\hline
\end{tabular}

c) トリップ变化率の想定

b) の結果より、図 4 の式を利用し、トリップ量変 化率を求めた結果が表 9 となる。

表 9 ビジネストリップ変化率

\begin{tabular}{|l|r|r|r|}
\hline & 管理的職業 & $\begin{array}{c}\text { 専門技術的 } \\
\text { 職業 }\end{array}$ & $\begin{array}{c}\text { その他の } \\
\text { 職業 }\end{array}$ \\
\hline シナリオ 1 & 1.05 & 1.05 & 0.99 \\
\hline シナリオ 2 & 0.98 & 0.97 & 0.91 \\
\hline
\end{tabular}

\section{（4）観光トリップ発生量の想定}

\section{a) 現状再現の重み付け}

現在の日本人の余层活動における志向性について は、日本観光協会編の「観光の実態と志向」8)の調查 結果を参考に A H P 手法の重み付けを行った。また、 制䄪条件についても同文献を参考にして現在の重み 付けを行った。

表 10 に、制約条件を考慮する前の余睱活動志向性 の想定結果、表 11 に、経済的制約、時間的制䄪の属 性毎の重要度とそれぞれの制䄪条件による実行割合 を考慮し求めた最終的な各余层活動の活動実行割合 を示す。

表 10 重み付け結果

\begin{tabular}{|c|c|c|c|c|c|}
\hline & 学生 & 独身 & $\begin{array}{l}\text { 夫壃 } \\
\text { 三人 }\end{array}$ & $\begin{array}{c}\text { 夫㛒+ } \\
\text { 子供 }\end{array}$ & $\begin{array}{c}\text { 夫婦 } \\
\text { 子供独立 }\end{array}$ \\
\hline$y y^{\prime}-12 x^{\circ}-7$ & $19.65 \%$ & $16.71 \%$ & $16.71 \%$ & $11.05 \%$ & $9.55 \%$ \\
\hline 是常称-y & $18.18 \%$ & $14.98 \%$ & $14.98 \%$ & $10.32 \%$ & $9.81 \%$ \\
\hline 国内近然離旅行 & $5.34 \%$ & $5.98 \%$ & $5.98 \%$ & $10.09 \%$ & $6.89 \%$ \\
\hline 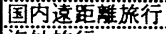 & $13.39 \%$ & $16.85 \%$ & $16.85 \%$ & $20.30 \%$ & $19.61 \%$ \\
\hline 海外旅行 & $22.42 \%$ & $26.38 \%$ & $26.38 \%$ & $20.79 \%$ & $10.97 \%$ \\
\hline 繁羔㖲薬 & $8.69 \%$ & $7.62 \%$ & $7.62 \%$ & $10.50 \%$ & $21.60 \%$ \\
\hline 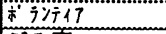 & $5.33 \%$ & $5.16 \%$ & $5.16 \%$ & $6.55 \%$ & $8.61 \%$ \\
\hline ごろ疫 & $7.00 \%$ & $6.32 \%$ & $6.32 \%$ & $10.40 \%$ & $12.95 \%$ \\
\hline 合計 & $100.00 \%$ & $100.00 \%$ & $100.00 \%$ & $100.00 \%$ & $100.00 \%$ \\
\hline
\end{tabular}

表 11 各余暇活動別の活動実行割合

\begin{tabular}{|c|c|c|c|c|c|}
\hline & 学生 & 独身 & 夫婦二人 & $\begin{array}{c}\text { 夫婦+子 } \\
\text { 供 }\end{array}$ & $\begin{array}{c}\text { 天婦子供 } \\
\text { 独立 }\end{array}$ \\
\hline リゾートスポーツ & $73.68 \%$ & $74.00 \%$ & $71.44 \%$ & $72.13 \%$ & $81.61 \%$ \\
\hline 日常スポーツ & $84.95 \%$ & $87.50 \%$ & $87.50 \%$ & $84.91 \%$ & $90.00 \%$ \\
\hline 国内近距離族行 & $78.23 \%$ & $84.78 \%$ & $84.52 \%$ & $78.55 \%$ & $85.83 \%$ \\
\hline 国内遠距離旅行 & $73.68 \%$ & $74.00 \%$ & $71.44 \%$ & $72.13 \%$ & $81.61 \%$ \\
\hline 海外旅行 & $19.89 \%$ & $28.21 \%$ & $32.14 \%$ & $27.29 \%$ & $50.00 \%$ \\
\hline 教養琛楽 & $84.95 \%$ & $87.50 \%$ & $87.50 \%$ & $84.91 \%$ & $90.00 \%$ \\
\hline 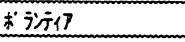 & $84.95 \%$ & $87.50 \%$ & $87.50 \%$ & $84.91 \%$ & $90.00 \%$ \\
\hline ごろ寝 & $100.00 \%$ & $100.00 \%$ & $100.00 \%$ & $100.00 \%$ & $100.00 \%$ \\
\hline
\end{tabular}




\section{b) 設定シナリオの重み付け}

表 3 の設定シナリオをもとに、表 12 の方針に従い シナリオに対応した重み付けを行った。

その重み付け結果を表 13 (シナリオ1)、表 14 (シナリオ 2 ) に示す。

表 12 想定シナリオに対応した重み付けの方針

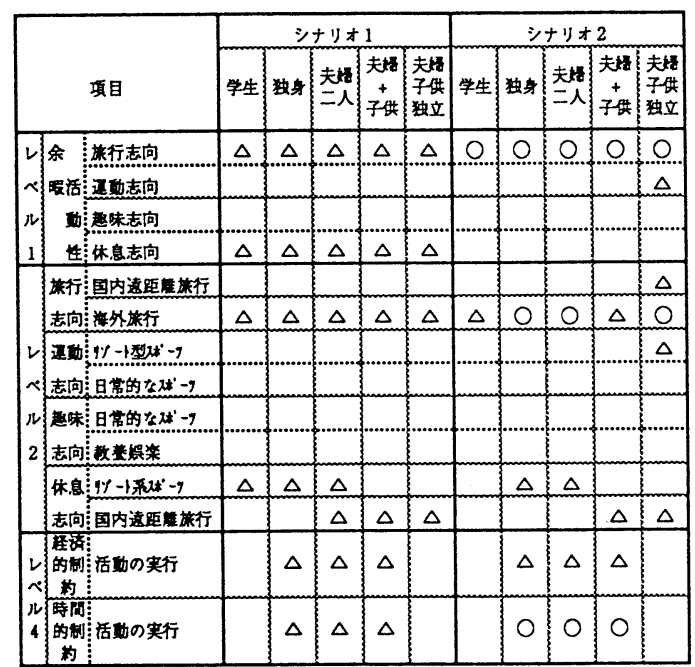

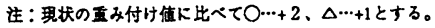

表 13 重み付け結果（シナリオ1）

\begin{tabular}{|c|c|c|c|c|c|}
\hline & 学生 & 独身 & $\begin{array}{l}\text { 夫婦 } \\
\text { 三人 }\end{array}$ & $\begin{array}{c}\text { 夫婦+ } \\
\text { 子供 }\end{array}$ & $\begin{array}{c}\text { 夫䀦 } \\
\text { 子供独立 }\end{array}$ \\
\hline 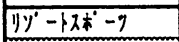 & $19.45 \%$ & $16.48 \%$ & $16.38 \%$ & $10.86 \%$ & $9.75 \%$ \\
\hline 日常示样-9 & $15.67 \%$ & $13.17 \%$ & $13.16 \%$ & $8.76 \%$ & $8.52 \%$ \\
\hline 国内近距政旅行 & $5.23 \%$ & $5.82 \%$ & $5.82 \%$ & $9.73 \%$ & $6.96 \%$ \\
\hline 国内遠距旗旅行 & $13.53 \%$ & $16.55 \%$ & $16.71 \%$ & $21.24 \%$ & $22.46 \%$ \\
\hline 海外旅行 & $26.14 \%$ & $29.73 \%$ & $29.72 \%$ & $23.70 \%$ & $13.57 \%$ \\
\hline 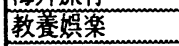 & $7.70 \%$ & $6.86 \%$ & $6.85 \%$ & $8.68 \%$ & $17.64 \%$ \\
\hline 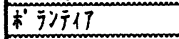 & $4.96 \%$ & $4.80 \%$ & $4.80 \%$ & $5.93 \%$ & $7.78 \%$ \\
\hline こ万震 & $7.31 \%$ & $6.58 \%$ & $6.56 \%$ & $11.10 \%$ & $13.32 \%$ \\
\hline 合計 & $100.00 \%$ & $100.00 \%$ & $100.00 \%$ & $100.00 \%$ & $100.00 \%$ \\
\hline
\end{tabular}

表 14 重み付け結果（シナリオ 2)

\begin{tabular}{|c|c|c|c|c|c|}
\hline & 学生 & 独身 & $\begin{array}{l}\text { 夫㛒 } \\
\text { 三人 }\end{array}$ & $\begin{array}{c}\text { 夫婦十 } \\
\text { 子供 }\end{array}$ & $\begin{array}{c}\text { 夫婦 } \\
\text { 子供独立 }\end{array}$ \\
\hline 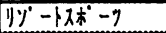 & $20.91 \%$ & $17.32 \%$ & $16.37 \%$ & $10.57 \%$ & $9.51 \%$ \\
\hline 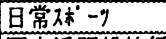 & $15.33 \%$ & $13.18 \%$ & $13.24 \%$ & $9.08 \%$ & $8.09 \%$ \\
\hline 国内近距旗旅行 & $5.35 \%$ & $5.92 \%$ & $6.09 \%$ & $10.63 \%$ & $7.29 \%$ \\
\hline 国内遠距崔旅行 & $13.09 \%$ & $16.01 \%$ & $16.74 \%$ & $20.86 \%$ & $25.14 \%$ \\
\hline 海外族行 & $26.45 \%$ & $29.98 \%$ & $30.01 \%$ & $25.26 \%$ & $15.72 \%$ \\
\hline 教呈姬楽 & $7.58 \%$ & $6.91 \%$ & $6.86 \%$ & $9.03 \%$ & $16.82 \%$ \\
\hline * YYF17 & $4.99 \%$ & $4.91 \%$ & $4.91 \%$ & $5.96 \%$ & $7.51 \%$ \\
\hline こ万妾 & $6.30 \%$ & $5.77 \%$ & $5.78 \%$ & $8.61 \%$ & $9.92 \%$ \\
\hline 合計 & & & & & \\
\hline
\end{tabular}

上記の想定のもとで、制約条件をクリアした最終的 な余晓活動選択結果を各属性の構成比で平均したも
のが図 6 である。

これによると、シナリオ1では旅行志向、海外旅行 志向の拡大が、時間的制約、経済的制約の楥和を受け て、現状に比へて顕在化し、国内遠距蜼旅行や海外旅 行が増加している。その一方で、日常スポーツ、教盖 娛楽といった余睱活動が減少する結果となっている。 シナリオ 2 では、旅行志向や海外旅行志向がシナリ オ 1 と比へて相対的にさらに拡大することや、時間 的制約の一層の楥和により、国内遠距蜼旅行、海外旅 行がシナリオ1と比べてさらに增加している。その 一方で、日常スポーツや教養娛楽、ごろ寝といった余 层志向性が減少する結果となっている。

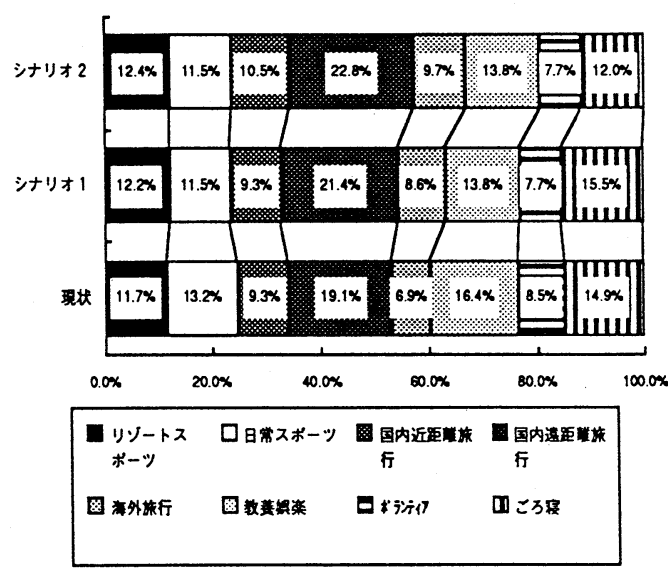

図 6 余良活動選択結果

次に、上記余睱活動の選択結果によって発生する、 属性別の 1 人あたりの観光トリップ発生量を示した のが図 7 である。旅行志向を強めたシナリオ 2 にお いて顕著な增加がうかがえる。

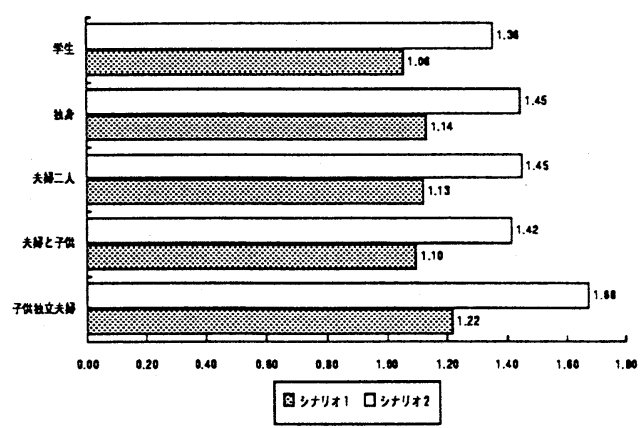

図 7 属性 1 人あたりの発生量変化率 


\section{6. 予測結果}

\section{(1) トリップ発生量の算定結果}

5.で求めた目的別トリップの変化率を使い、その 構成人口をかけることでトリップ発生量を求めた結 果が、図8、図9、図10である。

シナリオ 1 とシナリオ 2 で比較すると、ビジネスト

リッブについては、シナリオ 2 がシナリオ 1 より 7 \%程度少なくなっているが、観光トリップをみると、 逆にシナリオ 2 の方が $12 \%$ 程度多く、全体ではシ ナリオ 2 の方か $2 \%$ 程度多い結果となっている。

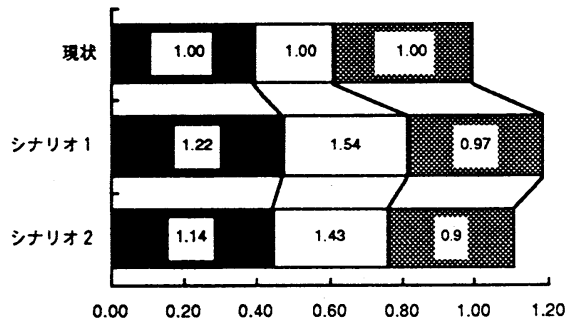

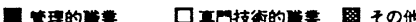

四 8 ビジネストリップ発生量（現状＝1）

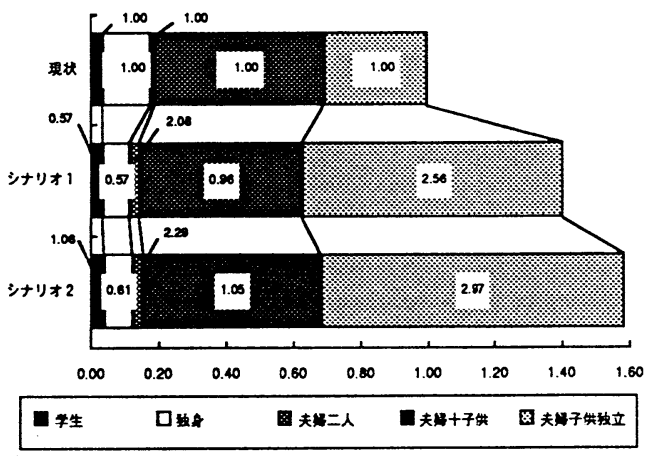

図 9 観光トリップ発生量（現状＝1）

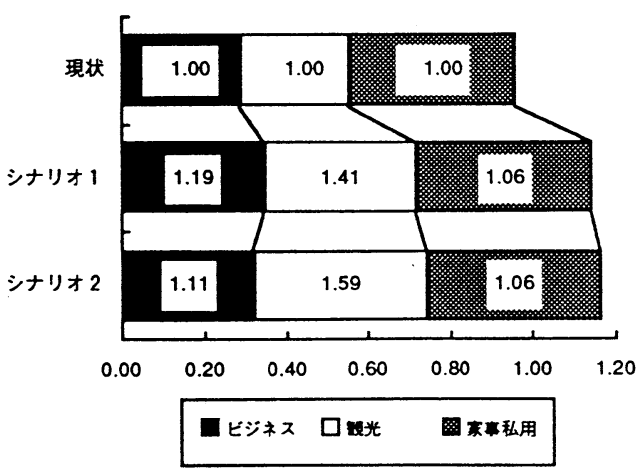

図 10 総トリップ発生量（現状＝1）
なお、図 8〜図10内の数字は、現状の各属性にお ける值を1とした場合の比率を示している。

\section{(2) 感度分析}

以上、2つのシナリオのもとに算定結果を提示した が、こでは、前項で述べた変動要素の大きい 4 つの 事柄について、感度分析を行う。

なお、図中の 1、0、一1はA H P 手法における各 要因の重み付けを 1 つ上げる（例えば 3 を 4 ）、変化 させない、1つ下げる（例えば、3を 2 ）ことを意味 している。

\section{ஓ) 時短、GDPの影䇾}

図11は、シナリオ1をベースにしてGDPと労働 時間についての感度を示したものである。どちらの 要因も、経済活動の根幹に影響を及はす要因であり、 ビジネストリップの発生量に及はす影響も大きい。

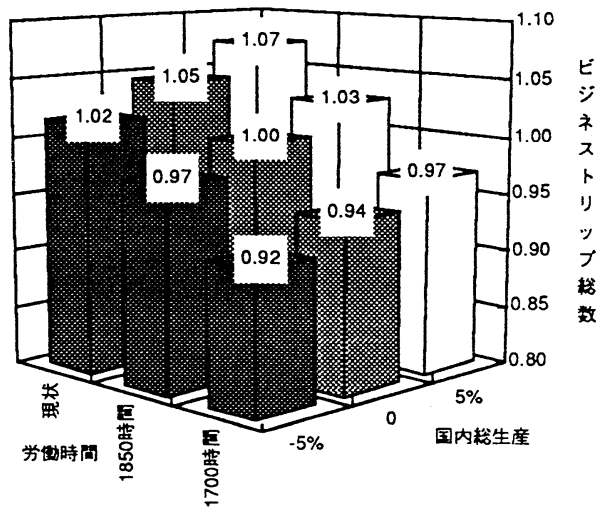

図 11 感度分析結果 (1)

\section{b）情報化の影響}

図12 は、シナリオ1をベースにして直接情報行動 量（現状ベース）とFace to Faceの重要性について の感度を示したものである。直接情報行動量の大小 は、トリッブに大きな影響を及はす一方でFace t 0 F a c eの重要性はほとんど影響を及はさない結果と なっている。これは、Face to Faceの重要性が弱ま るにつれて、トリッブが情報通信機器に代替される 一方、とりやめトリップ分の余裕時間の発生に伴い、 新たなビジネストリップが誘発されることが要因と なっている。 


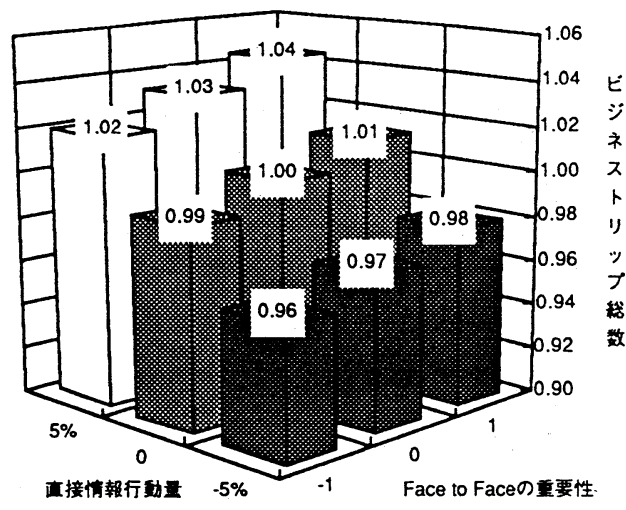

図 12 感度分析結果 (2)

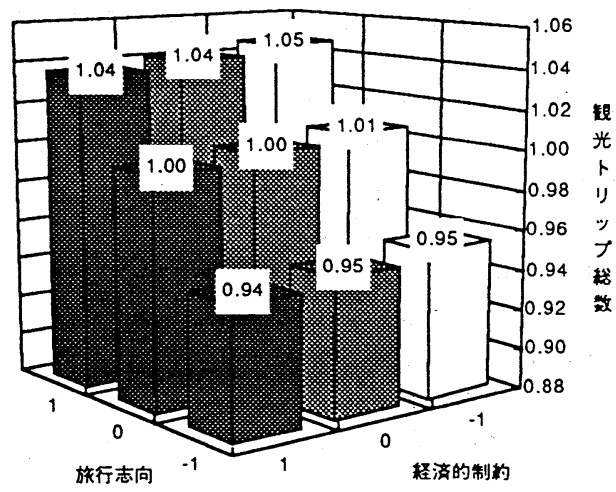

図 14 感度分析結果 (4)

\section{c) 余暇活動志向性の影響}

図 13 はシナリオ 2 をべースにして、旅行志向とそ の中での海外旅行の志向性の強弱による感度を示し たものである。旅行志向の感度が大きく、その一方 て、、海外旅行については若干のトリップ減の要因と なっていることがこの結果からわかる。

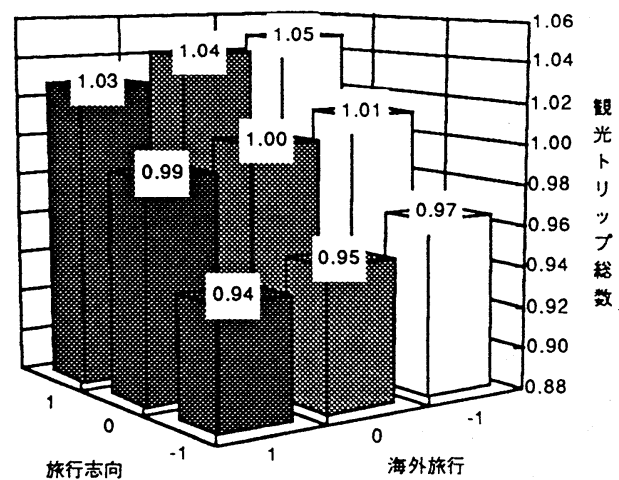

図13 感度分析結果（3）

\section{d) 経済的制約の影鰵}

また、図 14 は同じくシチリオ 2 をべースにして旅 行志向と経済的制約についての感度を示したもので ある。旅行志向の感度は前述の通りであるが、経済的

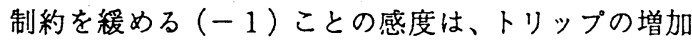
にあまり寄与していない。これは経済的制約を緩め ることで、図13が示すようにマイナス要素である 海外旅行が増加するためである。

7. まとめ

以上、新幹線計画を進めるにあたっての問題意識、 すなわち長期的展望の必要な新幹楾計画を、今後生 じる社会経済環境の構造変化の中で、いかに進めて いくかについての需要予測の一つの考え方を提案し、 その考えに基づいた具体例として、トリップ発生モ デルを提示した。

さらにこのモデルを使い、将来の社会経済環境の構

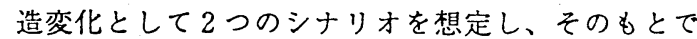
の算定結果を示した。

また構造変化のうち、変動要素の高い時短、情報化 の進渉、及び余㗇活動の变化、制約条件としての経済 的制䄪について、その変動によるトリップ発生量の 感度を分析した。その結果、ビジネストリップにおい ては、時短の影響は大きいものの、情報化による情報 機器への代替性については、発生する余裕時間によ り誘発する新たなトリップを考慮することで、結果 的に発生量には影響を余り与えないということが結 果から示された。観光トリップについては、旅行志向 の強弱の影響が大きいこと、さらに海外旅行の増加 が国内トリップの発生量にマイナスの影響を与える こと、さらには経済的制䄪が楥むことは、一方で上記 で述べた負の要素である海外旅行を増加させる要因 ともなり、全体としては微増にとどまることが結果 から示された。

このようにこのモデルを使い、様々な社会経済環境 を想定して演算を繰り返すことにより、個々の要因 の感度及び需要の全体像を把握することが、21世 紀の構造変化の中での需要予測にあたって必要だと 
いうのが主旨である。

今後残る課題としては、構造変化を表現する手法と

してAＨＰ手法を用いるにあたり、その階層構造の

同定、及び重み付けの妥当性をいかに評価し、そのも とでより良いモデルに改善していくかである。これ ら課題を整理する中で、本発生モデルを含む全体モ デルを用い、考えうる様々なシナリオのもとでの中 央新幹線の需要を算出し、それら需要算定値群をも とにした議論のもとで、望ましい中央新幹線計画を 進めていきたいと考えている。

最後に第 17 回土木計画学研究発表会において、京 都大学の北村隆一教授をはじめ多くの方々からご意 見とご指導をいただいたことに感謝の意を表します。

\section{参考文献}

1）土井利明・柴田洋三：21世紀の社会経済環境 の構造変化に対応する新たな需要予測手法に関 する考察, 運輸と経済，1994 年10月号

2 ) 土井利明・柴田洋三: 21 世紀の社会経済環境 の構造変化に対応した観光トリップ発生モデ ル, 土木計画学研究・講演集, No. 17
3）文世一：情報通信技術の進歩がオフィス企業の 交通需要と立地分布及び都市の规模に及はす影 響, 土木計画学研究・論文集, No．10

4）佐々木網，木下栄蔵：A H P よよる交通経路選 択特性の比較評価, 土木学会年次学術講演会講 演概要集, 第 4 部, 1986 年

$5 ）$ 溝上章志: 広域観光周遊トリップの需要予測手 法に関する一考察，土木学会西武支部研究発表 会, 講演概要集

6) 木下栄蔵；A H P 手法と応用技術，総合技術七 ンター, 1993 年

7）情報行動の長期予測に関する研究：電気通信粉 合研究所, 1983 年

8 ）日本観光協会編：観光の実体と志向，1990 年

9) 土木工学ハンドブック：土木学会編，1989 年

10 ) 交通需要予測ハンドブック：土木学会編，1 981 年

11）森地茂，山形耕一：交通計画，技報堂出版

21 世紀の社会経済環境の構造変化に対応したトリップ発生モデル

本研究は、今後の新幹線計画を進めるにあたり、加速度的に進むであろう社会経済環境の構造変化を考 慮する需要予測手法が必要との問題意識の中で、この構造変化に対応しうる発生交通量モデルを提示する ものである。モデル化にあたっては、トリップをその目的別に分け、それぞれのトリップの発生過程を意 思決定手法であるAHP (Analytic Hierarchy Process) 手法等を用い構造化し、その構造化された各要 因の重み付けを変化させることで、構造変化の影響を考慮した発生交通量を想定した。また、本モデルを 使い、いくつかの社会経済環境の構造変化のシナリオのもとでの発生交通量を想定し、その構造変化の影 響について考察を加えた。

Trip Generation Model Considering Structural Changes in Socioeconomic Environmento in the 21st Century

Toshiaki DOI and Yozo SHIBATA

This study proposes a trip generation model for use of future SHINKANSEN LINE, which can apply on various conditions, including both social and economic structural changes which might occur in the long term. The structural changes are modeled by scenario writing method by using Analytic Hierarchy Process(AHP). This study shows an applied examples, in which effects on trip generation caused by structural changes are evaluated. 